\title{
Detection of Hemoglobin D in Tharu Community of Banke, Nepal
}

\author{
Gupta $\mathrm{S}^{1}$, Kapoor $\mathrm{AK}^{2}$
}

\begin{abstract}
Background: Patients presenting with microcytic anemia, hepatosplenomegaly, abnormal hemoglobin level in electrophoresis and negative sickling test should have high suspicion for $\mathrm{HbD}$ disease. This occurrence is more in certain communities. While investigating the etiopathogenesis of subjects with microcytic anemia $(n=30)$, we came across 3 patients with $\mathrm{HbD}$ disease. Aim: Present study describes the clinical and hematological findings of 3 patients. Material and Methods: This was an observational study conducted between August, 2014 to July, 2015 in Department of Pathology of Nepalgunj Medical College. Of 30 patients diagnosed as microcytic anemia, 3 patients were selected. Results : The patients belonged to Tharu Chaudhary community of Banke district of Nepal. Age of the patients ranged from 8 to 13 years. All the patients had generalized pallor. Two of 3 patients had fever, joint pains and jaundice. One of the patients had hepatosplenomegaly. Total hemoglobin ranged from 7.1 to $8.4 \mathrm{gm} / \mathrm{dl}$. Patients had microcytic anemia. Sickling test was negative in all the 3 patients. Hemoglobin ( $\mathrm{Hb}$ ) electrophoresis revealed peaks in $\mathrm{HbS}$ region. Due to negativity of sickling test, the abnormal hemoglobin peak was interpreted as HbD. Thus, 2 patients had homozygous HbD disease while another patient had heterozygous $\mathrm{HbD}$ trait.
\end{abstract}

Key words: Anemia, HbDdisease, microcytic.

\section{INTRODUCTION}

Patients with anemia and abnormal $\mathrm{Hb}$ level are occasionally seen by us at Nepalgunj Medical College teaching hospital. These patients belong to Tharu community of Banke district. In this region, vivax malaria is also endemic. Plasmodium infection might have influenced the evolution of abnormal hemoglobins in mid-western region of Nepal.

$\mathrm{HbD}$ Punjab is most commonly found in India. It is identical to $\mathrm{HbD}$ Los Angeles ${ }^{1}$. It has also been found in Africa and Northern Europe1. Four forms of $\mathrm{HbD}$ disease may exist. First, heterozygous $\mathrm{HbD}$ trait, where $\mathrm{HbD}$ is about 30 to $40 \%$. This condition may be clinically silent. Second, homozygous $\mathrm{HbD}$ disease, where $\mathrm{HbD}$ is about $80 \%$ to $90 \%$, but most of homozygous $\mathrm{HbD}$ patients have normal red cell indices, no evidence of hemolysis and have normal $\mathrm{HbF}$ and $\mathrm{HbA} 2$ levels. Third, HbD thalassemia may cause mild hemolytic anemia, thalassemic red cell indices, no evidence of hemolysis and have normal $\mathrm{HbF}$ and $\mathrm{HbA} 2$ levels. Fourth, hemoglobin SD disease which causes moderate to severe sickling disorder ${ }^{2}$.

Herewith, we describe clinical and hematological features of 3 cases of $\mathrm{HbD}$ disease from this area.

\section{Dr. Sharmila Gupta \\ 2. Prof. A. K. Kapoor}

\section{Address for correspondence:}

Dr. Sharmila Gupta

Department of Pathology

Nepalgunj Medical College \& Teaching Hospital

Nepalgunj, Banke, Nepal

Email: drsharmilagupta@gmail.com

\section{MATERIAL AND METHODS}

This study was conducted at Nepalgunj Medical College, Nepalgunj from August, 2014 to July, 2015. Thirty subjects with microcytic anemia were selected for establishing their etiology. The subjects were prospectively recruited and preformed proforma was filled up. Subjects were collected from neighbouring areas, e.g. Banke, Bardiya and Dang. Detailed investigations revealed a diagnosis of $\mathrm{HbD}$ disease in 3 of 30 subjects. These 3 subjects were labeled as patients.

Present study was done on 3 patients with microcytic anemia. About $2.5 \mathrm{ml}$ of venous blood was collected from each patient in EDTA vial. Blood smears were also prepared and stained by Leishman method. Hemoglobin was estimated by cyanhemoglobin method. Hemogram was estimated using Nihon Kohden Celltac E, Europe GmbH, Rosbach Germany, a 5 parts differential coulter counter. It worked using the principle of volumetric impedance. Results of tests were obtained as hemoglobin $(\mathrm{Hb})$, hematocrit $(\mathrm{Hct})$, total red blood cell count (RBC), mean corpuscular volume (MCV), mean corpuscular hemoglobin $(\mathrm{MCH})$, mean corpuscular hemoglobin concentration (MCHC) and red cell distribution width (RDW).

Preparation of hemolysate

Two milliliter of EDTA blood was washed thrice with normal saline. The packed cells were lysed with distilled water and were centrifuged. Supernatant was collected as hemolysate and stored at $+4^{\circ} \mathrm{C}$.

Agarose gel electrophoresis at alkaline $\mathrm{pH} 8.6$ Hemolysate $(5 \mu \mathrm{l})$ was transferred into well plates using unit applicator, the sample was applied into the alkaline agarose gel along with suitable controls and immediately placed in electrophoresis chamber. The chamber was connected to a power supply and 
electrophoresed for $45 \mathrm{~min}$ at 100V. This was used to separate and identify different hemoglobins by their migration patterns within an electric field. This agarose gel was then transferred to a developer unit where it was fixed, stained, de-stained and dried for $50 \mathrm{~min}$. Later, agarose gel film was studied in computerized software (Biotec-Fischer GMBH 101, Germany).

\section{RESULTS}

Table I shows results of clinical findings of 3 patients with anemia. Age of patients ranged from 8 to 13 (median 9) years. All the patients had generalized pallor. Two patients had fever, joint pains and jaundice. Moderate hepatosplenomegaly was also detected in a patient (no.2).

Table II shows results of red cell indices in patients. Total hemoglobin ranged between 7.1 to $8.4 \mathrm{gm} / \mathrm{dl}$. Total RBC was relatively higher in patient no.3 as compared to RBC counts in two other patients.
Table III shows results of sickling tests and $\mathrm{Hb}$ electrophoresis. Sickling tests were negative in all the patients. However, separate peaks were seen in $\mathrm{HbS}$ region at alkaline $\mathrm{pH}$. Peaks in $\mathrm{HbS}$ region were interpreted as that of $\mathrm{HbD}$ due to negative sickling tests. Two patients had high level of $\mathrm{HbD}(88.7 \%$ and $99 \%)$, suggesting homozygous $\mathrm{HbD}$ disease. Another patient (patient no.3) had low level of $\mathrm{HbD}$ concentration (5.3\%). Therefore, in this patient, a diagnosis of heterozygous $\mathrm{HbD}$ disease ( $\mathrm{HbD}$ trait) was made. In this patient, $\mathrm{HbA}$ concentration was $94 \%$.

\section{DISCUSSION}

Most important feature of this study was the detection of peaks in the region of $\mathrm{HbS}$. Due to its failure to produce sickling, these peaks were interpreted as that of $\mathrm{HbD}$ and these patients were diagnosed as suffering from $\mathrm{HbD}$ disease $(\mathrm{HbS}$ and $\mathrm{HbD}$ are known to have similar mobility at alkaline $\mathrm{pH}$. However, they can be separated by agar gel electrophoresis at an acid $\mathrm{pH}$ ).

\begin{tabular}{|c|c|c|c|c|c|c|c|}
\hline $\begin{array}{c}\text { Patient } \\
\text { no. }\end{array}$ & $\begin{array}{c}\text { Age } \\
\text { Yrs. }\end{array}$ & Pallor & Fever & $\begin{array}{c}\text { Joint } \\
\text { Pain }\end{array}$ & Jaundice & Liver & Spleen \\
\hline 1 & 13 & + & + & + & + & $\mathrm{np}$ & $\mathrm{np}$ \\
\hline 2 & 8 & + & + & + & + & $\mathrm{cm}$ & $9 \mathrm{~cm}$ \\
\hline 3 & 9 & + & - & - & - & $\mathrm{np}$ & $\mathrm{np}$ \\
\hline
\end{tabular}

$\mathrm{np}=$ non-palpable

Table I : Shows clinical findings in patients with $\mathrm{HbD}$ disease.

\begin{tabular}{|c|c|c|c|c|c|c|c|c|}
\hline $\begin{array}{c}\text { Patient } \\
\text { no. }\end{array}$ & $\begin{array}{c}\text { Hb } \\
\mathbf{g m} / \mathbf{d l}\end{array}$ & $\begin{array}{c}\text { Hct } \\
\mathbf{c c} \%\end{array}$ & $\begin{array}{c}\text { RBC } \\
\mathbf{m i l l i o n} \\
\mathbf{m m} 3\end{array}$ & $\begin{array}{c}\text { MCV } \\
\text { fl }\end{array}$ & $\begin{array}{c}\text { MCH } \\
\mathbf{p g}\end{array}$ & $\begin{array}{c}\text { MCHC } \\
\mathbf{c c} \%\end{array}$ & $\begin{array}{c}\text { RDW } \\
\%\end{array}$ & $\begin{array}{c}\text { Reticulocyte } \\
\%\end{array}$ \\
\hline 1 & 7.9 & 24.3 & 3.36 & 72.3 & 23.5 & 32.5 & 17.9 & 2 \\
\hline 2 & 7.1 & 24.2 & 3.19 & 75.9 & 22.3 & 29.3 & 19.6 & 1.5 \\
\hline 3 & 8.4 & 24 & 5.2 & 74 & 23 & 32 & 14 & 1.1 \\
\hline
\end{tabular}

Table II : Results of red cell indices in 3 patients with HbD disease.

\begin{tabular}{|c|c|c|c|c|c|c|c|c|}
\hline \multirow{2}{*}{$\begin{array}{c}\text { Patient } \\
\text { no. }\end{array}$} & $\begin{array}{c}\text { Sickling } \\
\text { test } \\
+/-\end{array}$ & $\begin{array}{c}\mathrm{HbA2} \\
\%\end{array}$ & $\begin{array}{c}\mathrm{HbD} \\
\%\end{array}$ & $\begin{array}{c}\mathrm{HbF} \\
\%\end{array}$ & $\begin{array}{c}\mathrm{Hb} \mathrm{b} \\
\%\end{array}$ & $\begin{array}{c}\text { Globin } \\
\text { genotype }\end{array}$ & $\begin{array}{c}\text { Globin } \\
\text { phenotype }\end{array}$ & $\begin{array}{c}\text { Clinical } \\
\text { diagnosis }\end{array}$ \\
\hline 1 & - & 11.3 & 88.7 & - & - & $\alpha_{2} \beta^{\mathrm{D}} / \beta^{\mathrm{D}}$ & $\alpha_{2} \beta^{\mathrm{D} \uparrow \uparrow \uparrow}$ & $\begin{array}{c}\text { Homozygous } \\
\text { HbD disease }\end{array}$ \\
\hline 2 & - & 1 & 99 & - & - & $\alpha_{2} \beta^{\mathrm{D}} / \beta^{\mathrm{D}}$ & $\alpha_{2} \beta^{\mathrm{D} \uparrow \uparrow \uparrow}$ & $\begin{array}{c}\text { Homozygous } \\
\text { HbD disease }\end{array}$ \\
\hline 3 & - & 0.7 & 5.3 & - & 94 & $\alpha_{2} \beta \beta^{\mathrm{D}}$ & $\alpha_{2} \beta \uparrow \uparrow \beta^{\mathrm{D}} \uparrow$ & $\begin{array}{c}\text { Heterozygous } \\
\text { HbAD disease } \\
\text { (HbD trait) }\end{array}$ \\
\hline
\end{tabular}

+ positive, - negative

Table III : Results of sickling test and hemoglobin electrophoresis in patients with $\mathrm{HbD}$ disease 
Two of 3 patients had high percentage of $\mathrm{HbD}$ ( $88.7 \%$ and $99 \%)$. In these 2 patients, a diagnosis of homozygous $\mathrm{HbD}$ disease ( $\mathrm{HbDD}$ ) was made. Another patient (patient no.3) had low level of $\mathrm{HbD}(5.3 \%)$. In this patient, a diagnosis of heterozygous $\mathrm{HbD}$ disease (HbAD trait) was made.

$\mathrm{HbD}$ disease is caused by $\beta$ chain mutation at position 121 , where glutamine replaces glutamic acid ${ }^{2}$. Homozygous $\mathrm{HbD}$ disease (HbDD) is characterized by a mild microcytic anemia, poikilocytosis, minimal hemolysis and mild to moderate splenomegaly $^{3}$. Osmotic fragility may be decreased ${ }^{1}$.

All the patients had moderate anemia. In addition, one of the patients with homozygous $\mathrm{HbD}$ disease (no.2) had moderate hepatosplenomegaly. Two patients with homozygous $\mathrm{HbD}$ disease had jaundice. Jaundice might have developed as the result of excessive hemolysis, leading to rise in unconjugated bilirubin.

The patient with heterozygous disease (no.3) had relatively milder disease as compared to other 2 patients with homozygous $\mathrm{HbD}$ disease. High level of $\mathrm{HbA}$ in this patient might have resulted in a milder disease. Heterozygous $\mathrm{HbD}$ disease may be clinically silent ${ }^{4-5}$. However, severe hemolysis developed in an $\mathrm{HbD}$ trait mother following physiological stress during twin pregnancy ${ }^{6}$. In addition, clinical variation in the behavior of $\mathrm{HbD}$ traits may occur. In a previous study ${ }^{5}, 6$ of 30 patients with $\mathrm{HbD}$ traits were symptomatic. A rare case of $\mathrm{HbD}$ trait has been described in a 1 year old child having jaundice, hepatosplenomegaly and hemolytic anemia ${ }^{7}$.

\section{CONCLUSION}

$\mathrm{HbD}$ disease is an uncommon condition present in Tharu community of Midwestern Nepal. Two of the 3 patients had rare homozygous $\mathrm{HbD}$ disease while another patient had heterozygous $\mathrm{HbD}$ disease

\section{Conflict of Interest: None}

\section{REFERENCES}

1. Natarajan K, Townes TM and Kutlar A. Disorders of hemoglobin structure : sickle cell anemia and related abnormalities In : Kaushansky K, Lichtman MA, Beutler E et al, editors. Williams Hematology, New York, McGraw Hill Medical 2010, 8th ed, p70941.

2. Shukla A, Dabadghao S, Gupta S, Verma S.Interference of HbD Punjab on measurements of glycosylated hemoglobin. Ind J Pathol \& Microbiol 2015; 58: 572-4.

3. Lukens JN : Hereditary disorders of hemoglobin structure and synthesis. In :Greer JP, Foerster J, Rodgers GM et al editors. Wintrobe'sclinical hematology,Philadelphia : Lippincot Williams and Wilkins 2004, 7th ed, p1259.
4. Desai D, Dhanani H, Sah M, Dayal N, Kapoor A, Yeluri. Homozygous hemoglobin $D$ disease : A case report. Internet J Path, 2003;3: 1-4.

5. Pandey S, Mishra RM, Pandey S, Vineet Shah, Saxena R. Molecular characterization of hemoglobin D Punjab traits and clinical hematological profile of the patients. Sao Paulo Med J 2017; 130(4): 248-251.

6. Anuradha N, Anuradha CR, Raghav J 2014. Haemoglobin-D A rare case report 2014; 10(4): 484-487

7. Hemlatha AL, Shobha SN, Indira CS, Raghuveer CR. Hemoglobin D - Punjab trait of Non-Punjabi heritage in Karnataka. South India : An exceptionally rare occurrence. International J Scientific study 2015; 3:189-191. 